\title{
Effect of medium strength and activated charcoal on in vitro shoot multiplications and growth of jojoba
}

\author{
A.M. Hassanein, A. Galal, D.M. Soltan, G.k. Saad \\ Central Laboratory of Genetic Engineering, Sohag University, 82524 Sohag, Sohag, Egypt. \\ Rec. 3 Sept, 2015 Accept. 17 Oct, 2015
}

\begin{abstract}
In vitro grown plant materials of jojoba plant (Simmondsia chinensis L.) were used to study the effect of medium strength and activated charcoal (AC) on shoot multiplication and growth. Reduction in shoot multiplication was detected when explants were cultured on half strength MS medium. The highest shoot multiplication was obtained on the full strength MS medium containing $3.0 \mathrm{mg} / \mathrm{l} \mathrm{BAP}$ and $0.1 \mathrm{mg} / \mathrm{l} \mathrm{NAA}$. Increase the osmotic pressure of the medium by increasing the concentrations up to double strength MS medium resulted in an increase of the growth parameters. Jojoba multiplication and in vitro growth was improved using activated charcoal; the best results were obtained on MS medium supplemented with $1 \mathrm{gm} / 1$ activated charcoal, $3 \mathrm{mg} / \mathrm{l} \mathrm{BAP}$ and $0.1 \mathrm{mg} / \mathrm{l} \mathrm{NAA}$. While gene expression was stable under the influence of activated charcoal, it expressed some variation under the influence of medium strength. On the other hand, full medium strength resulted in maximum shoot multiplication and expressed several polypeptides with different molecular weights $(150,102.6,65$ and $42 \mathrm{KDa})$ and new peroxidase isoform (POX-1). Double strength MS medium expressed one polypeptide (8.6 KDa). Increased staining intensity of peroxidases and stimulate shoot growth.
\end{abstract}

Keywords: Charcoal, esterase, micropropagation, peroxidase, protein pattern.

\section{Introduction:}

Simmondsia chinensis (Link) Schneider is the sole species in the family Simmondsiaceae and commonly known as jojoba. It is longlived evergreen perennial woody desert shrub native to Sonoran desert of Arizona, South Western USA and Northern Mexico (Hogan, 1979; Mills et al., 1997). Due to its ability to tolerate several stresses and the economical importance of its liquid wax, jojoba is grown commercially in several countries such as Australia, Argentina, Egypt and India. Jojoba wax is used as replacement for sperm whale in several manufactures (Mills et al., 1997; Benzioni et al., 1999). Jojoba wax is used as an efficient lubricant over a wide range of temperatures (Yermanos, 1979: Low and Hackett 1981; Wang and Janick 1986). Jojoba oil is also used as anti-foaming agents and resins (Bashir et al., 2008).

Propagation of jojoba can be established using seeds, seedlings and stem cuttings.
While the conventional vegetative propagation using stem cuttings is widely used, some difficulties and constrains of this procedure makes the application of in vitro technique is the most interesting one for jojoba propagation. For example, jojoba is dioecious plant species and true-to-type by sexual propagation is not guaranteed (Chaturvedi and Sharma, 1989). In addition, vegetative propagation in jojoba was established by rooting of semi-hardwood cuttings but the maximum number of possible propagules is limited by plant size (Low and Hackett, 1981; Lee, 1988; Cao and Gao, 2003). Tissue culture obtained plants free from pathogens and grow more vigorously than others obtained from seedlings or vegetative propagation (Lee, 1988; Mohasseb et al., 2009).

Different ingredients of inorganic and organic salts as well as inert supportive materials were used to culture plant cell, tissue or organ under in vitro conditions (Huang and

\footnotetext{
* Corresponding author:

Dr. A.M. Hassanein

$凶$ hassaneinam@yahoo.com
}

81 
Murashige, 1977). These ingredient as a chemical factors with other physical factors determine the success of cultures. In plant tissue culture techniques, activated charcoal is recommended (Lu et al., 1990). due to its structure with a very fine network of pores creating large inner surface area where many substances can be adsorbed (Pan and van staden 1998). Consequently, activated charcoal improves cell growth and development.

Gene expression can be studied by SDS PAGEs and isoenzymes to explain how plants are affected by developmental stages and stress agents. Implication of specific polypeptides in metabolism of plants under stress and tissue culture conditions was suggested (Radic and Pevaler-kozlina, 2010). Increase or decrease in the staining intensity of isoenzyme band represents a negative or positive change in enzyme activity (Khavkin and Zabrodina 1994; Hassanein et al., 1999a). indicating that the gene involved in the synthesis of this isoenzyme form is differentially activated under specific condition (Chawla, 1991; Hassanein et al., 1999a, ; EI- Tayeb and Hassanein 2000).

Gene expression is influenced by biotic and abiotic factors. In jojoba as oil producing plant and tolerates stress conditions, gene expression is not fully understood. Consequently, the aim of this work was to study the effect of medium strength and activated charcoal on gene micropropagation and gene expression.

\section{Materials and methods: \\ Plant materials:}

Jojoba seeds were obtained from the Egyptian Natural Oil Co. S. A. E., Ismailia Farm, Salam Zone, Manayef, Ismailia, Cairo, Egypt. The farm was planted in Ismailia in 1991 and it was used for research and production. To establish shoot culture of jojoba, seeds were germinated in plastic pots under room condition. Nodeal segments were collected from one year old plants and subjected for sterilization in 5\% clorox solution for four minutes followed by ethyl alcohol $70 \%$ contained drops of Twin 20 for further four minutes, then nodes were washed by sterilized distilled water three times, three minutes each. After sterilization, the ends of each nodal segment were discarded to reach maximum $1.5 \mathrm{~cm}$ long with one node prior to transfer to MS medium (Murashige and Skoog 1962).

The used MS medium was supplemented with $3 \%$ sucrose, $3 \mathrm{mg} / 1 \delta$-benzylaminopurine (BAP) and $0.1 \mathrm{mg} / \mathrm{l}$ Naphalene acetic acid (NAA). The medium was solidified with $0.8 \%$ agar at $\mathrm{pH}$ 5.8. Medium sterilization was done by autoclaving at $121^{\circ} \mathrm{C}$ for 20 minutes. Cultures were incubated in tissue culture room $\left(28 \pm 2{ }^{\circ} \mathrm{C}\right.$ with 16 -h photoperiod at $100 \mu \mathrm{mol}$ m-2 s-1). Thirty explants were used for each treatment. Regeneration frequency (\%), number of shoots per explants, length of shoots $(\mathrm{cm})$, number of leaves per shoot, and number of nodes per shoot were estimated.

\section{Jojoba shoots multiplication and growth as influenced by medium strength:}

Shoots $(1.5 \mathrm{~cm})$ obtained from in vitro grown plant materials were cultured on MS medium at different salt strengths: half strength, full strength, one and half full strength and double full strength. All the used media were supplemented with $3 \mathrm{mg} / \mathrm{l}$ BAP and $0.1 \mathrm{mg} / \mathrm{l} \mathrm{NAA}$. Cultures were incubated under tissue culture condition ( $16 \mathrm{~h}$ daily light at $100 \mu \mathrm{mol} \mathrm{m}-2 \mathrm{~s}-1)$ at $28 \pm 2{ }^{\circ} \mathrm{C}$. After incubation period, length of shoots, number of leaves per shoot, and number of nods per shoot were determined.

To study gene expression of the jojoba cultivars, two isoenzymes were visualized; they were peroxidase (POX) and esterase (EST). In addition, shoots grown on different media strengths were collected, and subjected for SDS-PAGE analysis. Protein bands were visualized using Coomassie blue dye.

Effect of activated charcoal and several growth regulator concentrations on jojoba shoots growth and multiplication:

Jojoba microshoots were cultured on MS medium contained $1 \mathrm{gm}$ activated charcoal and several concentrations of phytohormones: MS medium without growth regulators, MS with 4 $\mathrm{mg} / \mathrm{l} \mathrm{BAP}$ and MS with $3 \mathrm{mg} / \mathrm{l} \mathrm{BAP}$ and 0.1 mg/l NAA. Shoot length, leaves number per shoot, node number per shoot, fresh weight, 
and number of shoots per explant were estimated after six weeks. Shoots were incubated under tissue culture conditions $(16 \mathrm{~h}$ daily light at $100 \mu \mathrm{mol} \mathrm{m}-2 \mathrm{~s}-1)$ at $29 \pm 1{ }^{\circ} \mathrm{C}$.

Effect of low concentrations of BAP and NAA as well as different concentrations of activated charcoal on shoot multiplication and shoot growth:

Microshoots were transferred to half strength MS medium supplemented with 1.25 $\mathrm{mg} / \mathrm{l} \mathrm{BAP}+1.3 \mathrm{mg} / \mathrm{l} \mathrm{NAA}$ and $0.5,1,2$, and 3 $\mathrm{g} / \mathrm{l}$ activated charcoal. The shoots were incubated at $30^{\circ} \mathrm{c}$ and 250 lux. After four weeks, shoots number per explants, shoot length, number of leaves, and number of node per shoot were determined.

\section{Isoenzyme analysis:}

One gram of the plant material was ground on ice in a mortar using $1 \mathrm{~cm} 30.04 \mathrm{M}$ Tris$\mathrm{HCl}, \mathrm{pH} 7.0$, containing $0.002 \mathrm{M}$ cysteine and was used for esterase detection. In case of SDS-PAGE the buffer contained $0.25 \mathrm{M}$ Tris$\mathrm{HCl}, \quad \mathrm{pH} \quad 8.5$, and $0.3 \%(\mathrm{v} / \mathrm{v}) \quad 2-$ mercaptoethanol. In both cases, the homogenate was centrifuged at $15000 \mathrm{~g}$ at $4^{\circ} \mathrm{C}$ for $15 \mathrm{~min}$. native PAGE was performed in $7.5 \%$ acrylamide slab gels. Protein samples were loaded onto the gel wells for electrophoresis. Gels were run at $10 \mathrm{~mA}$ per gel for $6 \mathrm{~h}$ at $4{ }^{\circ} \mathrm{C}$ with $0.025 \mathrm{M}$ Tris- $\mathrm{HCl}+$ $0.192 \mathrm{M}$ glycine buffer, $\mathrm{pH} 8.9$

\section{Peroxidase detection:}

The peroxidase bands were stained by phosphate buffer, Guaiacol and $\mathrm{H}_{2} \mathrm{O}_{2}$ as described by Siegel and Galston 1967.

\section{Esterase detection:}

The esterase bands were stained by $\alpha$ - and $\beta$-naphthyl acetate with blue RR salt as described by Brewer (1970) and Chibbar et al., (1988).

\section{SDS PAGE Analysis:}

Approximately 1 gram fresh plant materials were ground in a mortar and pestle in liquid nitrogen. Crashing continued until the plant materials were completely homogenized. The crushed samples were mixed with $1 \mathrm{ml}$ extraction buffer $(50 \mathrm{mM}$ Tris- $\mathrm{HCl}$ buffer, $\mathrm{pH}$ 6.8, glycerol $10 \% \mathrm{w} / \mathrm{v}$, ascorbic acid $0.1 \%$, cysteine hydrochlode $0.1 \% \mathrm{w} / \mathrm{v})$. The samples were subjected for centrifugation at $15000 \mathrm{rpm}$ for $30 \mathrm{~min}$. Electrophoresis was performed using $11 \%$ polyacrylamide gel at $10{ }^{\circ} \mathrm{C}$ and 60 mA according Laemmli (1970). Coomassie blue staining method for the SDS PAGE was performed.

\section{Statistical analysis:}

Treatments were compared by LSD test at the 5\% level of significance $(\mathrm{p}=0.05)$.

\section{Results and Discussion}

One year old plants were used as a source of explants in this work. Nodal explants were sterilized as described in materials and methods section and transferred to induce shoot multiplication on MS medium supplemented with $3 \mathrm{mg} / \mathrm{l} \mathrm{BAP}$ and $0.1 \mathrm{mg} / \mathrm{l}$ NAA.P. Then, these in vitro grown plant materials were used to study the effect of medium strength on shoot multiplication and growth. The obtained data indicated that the number of formed shoots was significantly decreased when the concentrations of MS components were more than or less than full strength MS components (Table 1). The highest shoot multiplication was obtained on the full strength MS medium containing $3.0 \mathrm{mg} / \mathrm{l} \mathrm{BAP}$ and $0.1 \mathrm{mg} / \mathrm{l} \mathrm{NAA}$ as was reported previously by Hassanein et al., (2015). Generally, the calculated growth parameters increased when the explants were cultured on MS medium with chemical components higher than that of the normal basal MS medium (full strength). In jojoba as stress tolerant plant species (Al-Ani et al., 1972), increase the osmotic pressure of the medium by increasing the concentrations of medium components stimulated jojoba growth. In general, decrease the concentration of MS components to half strength resulted in a decrease in the values of the measured parameters. On the other hand, (Mohasseb et al., 2009). found that half strength MS medium containing growth regulators established multiple shoot formation in jojoba but the used medium did not support shoot growth where they remained compact and stunted, and they needed full strength MS medium to continue normal growth.

The highest leaf number/shoot was obtained when the jojoba shoots were cultured for 8 weeks on double strength MS medium supplemented with $3 \mathrm{mg} / \mathrm{l} \mathrm{BAP}$ and $0.1 \mathrm{mg} / \mathrm{l}$ 
NAA (Fig. 1). Under the high concentration of MS components more than one leaf/ node was formed, where two or three leaves/ node were detected. On the other side, when the concentration of MS components were reduced to less than double strength MS medium, sometimes one leaf/ node was formed. Therefore the number of leaves/ node was not in accordance with the number of nodes/shoot.

\begin{tabular}{|c|c|c|c|c|c|}
\hline MS strength & $\begin{array}{c}\text { Number of } \\
\text { shoots/ ex4plant }\end{array}$ & $\begin{array}{c}\text { Length of } \\
\text { shoot (cm.) }\end{array}$ & $\begin{array}{c}\text { Number of } \\
\text { leaves/ shoot }\end{array}$ & $\begin{array}{c}\text { Number of } \\
\text { nodes/ shoot }\end{array}$ & $\begin{array}{c}\text { Shoot fresh } \\
\text { weight (g) }\end{array}$ \\
\hline Half & $4^{*}$ & $3.6^{*}$ & $10^{*}$ & $5^{*}$ & $0.18^{*}$ \\
\hline Full & 12 & 6 & 12 & 7 & 0.3 \\
\hline One and half full & $7^{*}$ & $7^{*}$ & $10^{*}$ & $5^{*}$ & 0.36 \\
\hline Double full & $7^{*}$ & $7.8^{*}$ & $15^{*}$ & 6 & 0.38 \\
\hline
\end{tabular}

Table (1): Effect of medium strength on in vitro grown shoots on MS medium supplemented with $3 \mathrm{mg} / \mathrm{l}$ BAP and $0.1 \mathrm{mg} / \mathrm{l} \mathrm{NAA}$ for eight weeks.

* Means significantly different (t-test) from jojoba shoots cultured on full MS medium supplemented with $3 \mathrm{mg} / \mathrm{l} \mathrm{BAP}$ and $0.1 \mathrm{mg} / \mathrm{l}$ NAA at $\mathrm{P}<0.05$.

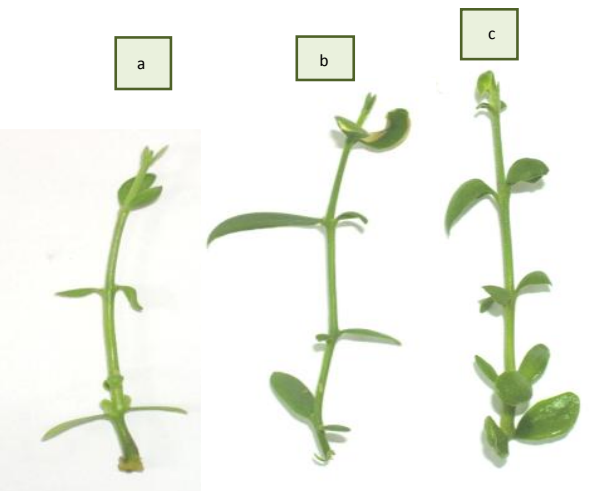

Fig. (1): Photograph showing in vitro shoot growth under the influence of medium strength (MS) containing $3 \mathrm{mg} / \mathrm{l} \mathrm{BAP}$ and $0.1 \mathrm{mg} / \mathrm{l} \mathrm{NAA:} \mathrm{(a)} \mathrm{shoot} \mathrm{was} \mathrm{incubated}$ in glass jar containing full strength MS medium; (b) one and half strength MS medium and (c) double strength MS medium for eight weeks.

Gene expression was studied under the influence of medium strength. SDS-PAGE pattern of jojoba shoots grown for one week on different salt strengths of MS medium was studied (Fig. 2). Gel analysis indicated that, about 30 polypeptides with apparent molecular weight ranging from 8.6-200 $\mathrm{KDa}$ were detected. The synthesis of polypeptides in jojoba shoots was not strongly influenced by the concentration of MS components. The highest staining intensity of polypeptide bands was detected when jojoba shoots were subcultured on full strength MS medium under tissue culture condition (Lane 2). On contrast, the lowest staining intensity of polypeptide bands was detected when jojoba shoots were subcultured on one and half full strength MS medium (Lane 3). Bands with different molecular weights $(150,102.6,65$, and 42.6 $\mathrm{KDa}$ ) were detected when jojoba shoots were subcultured on half or full strength MS medium. On the other hand, the polypeptide of molecular weight of $8.6 \mathrm{KDa}$ was detected when shoots were subcultured on double full strength MS medium (Lane 4) and it was not detected in shoots subjected to the other treatments.

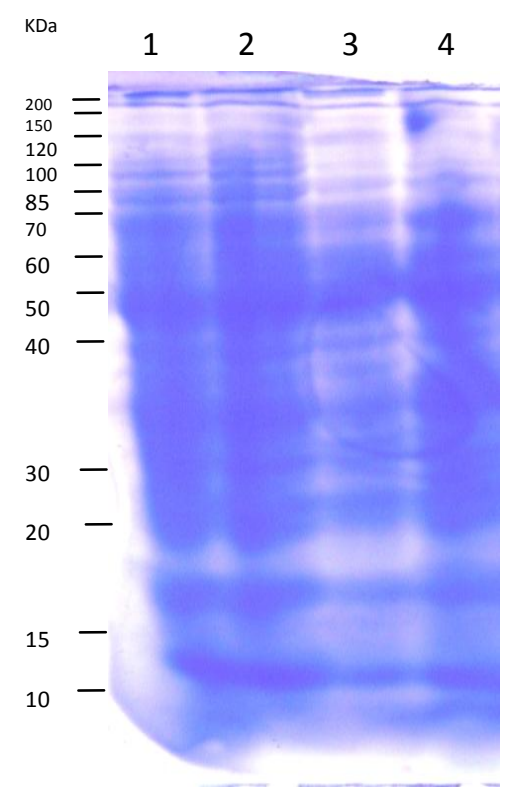

Fig. (2): SDS-PAGE of jojoba shoots were grown under the influence of different medium strength containing 3 $\mathrm{mg}$. BAP and $0.1 \mathrm{mg}$. NAA for one week. Lane 2: jojoba shoots on full strength MS medium, Lane 1, 3, and 4 represent jojoba shoots on half, one and half, and double full MS strength, respectively.

To study the effect of medium strength on peroxidase expression, jojoba shoots were 
subcultured on different MS salt strengths for one week and subject to isoperoxidase analysis (Fig.3). When conditions stimulated shoot multiplication on full strength MS medium or more were used, one new peroxidase band (POX-1) was detected (Fig. 3). In addition, staining intensity of several isoenzyme bands were progressively increased with the increase of MS strength. The highest staining intensity was detected when plant materials were cultured on one and half or double strength MS medium. It indicated that increase of peroxidase activity was necessary for establishment of shoot multiplication and improvement of shoot growth. The increase of the enzyme activity was illustrated by increase the number of isoenzyme forms and/or the increase in the staining intensity of isoenzyme bands (Khavkin and Zabrodina 1994, Hassanein, 1998; 2004 a, b). The regeneration potential of the cultured tissue was dependent on both scavenging potential and the ability to produce $\mathrm{H}_{2} \mathrm{O}_{2}$ through NADH-POX activity. Phenol oxidases use phenolic compounds to scavenge the reactive oxygen species (Nicholson and Hammerschmidt 1992; Benson and Roubelakis-Angelakis 1994; Elstner and Osswald 1994).

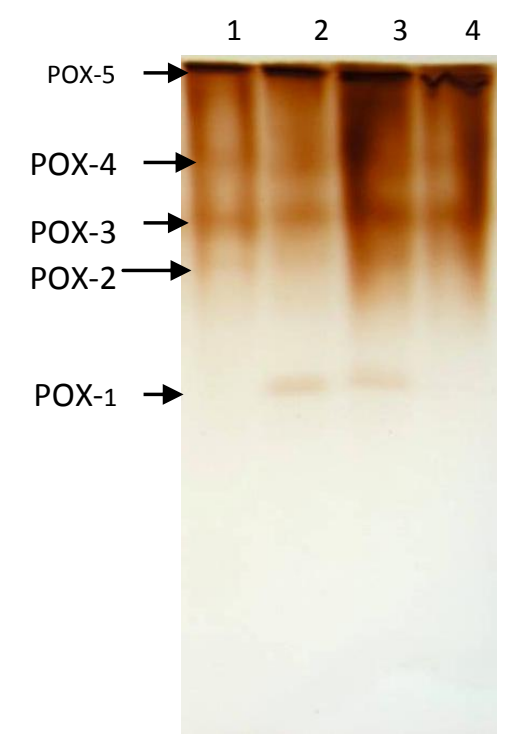

Fig. (3): Native gel electrophoresis of POX isoenzyme pattern of jojoba shoots grown under the influence of different MS medium strength containing $3 \mathrm{mg} / \mathrm{l}$ BAP and $0.1 \mathrm{mg} / \mathrm{l}$ NAA for one week. Lane 2: jojoba shoots on full strength MS medium, lanes 1, 3, and 4 jojoba shoots on half, one and half, and double full MS strength, respectively.

Esterase (EST) expression under the influence of different medium salt strengths was visualized in Figure 4. A total of 16 different EST isoenzyme forms were detected. Each MS strength expressed identical pattern. One isoenzyme forms (EST-1) was detected when jojoba shoots were subcultured on full MS strength medium supplemented with 3 $\mathrm{mg} / \mathrm{l}$. BAP and $0.1 \mathrm{mg} / \mathrm{l} \mathrm{NAA}$ for one week (Lane 2), this band could not be detected under the other applied conditions. While distinct pattern of EST was expressed when the shoot cuttings were cultured on full or double strength of MS medium, where two EST bands (EST-7 and EST-16) were detected (lane 2 and 4), the staining intensity of bands of shoots cultured on double strength MS medium was higher than that under full strength MS medium. In addition, one isoenzyme form (EST-9) was only detected when jojoba shoots were subcultured on double MS strength (Lane 4), this isoenzyme form could not be detected under the other applied conditions. Distinct isoenzyme form (EST-15) could only be detected when the plant materials were subcultured on 1.5 MS strength.

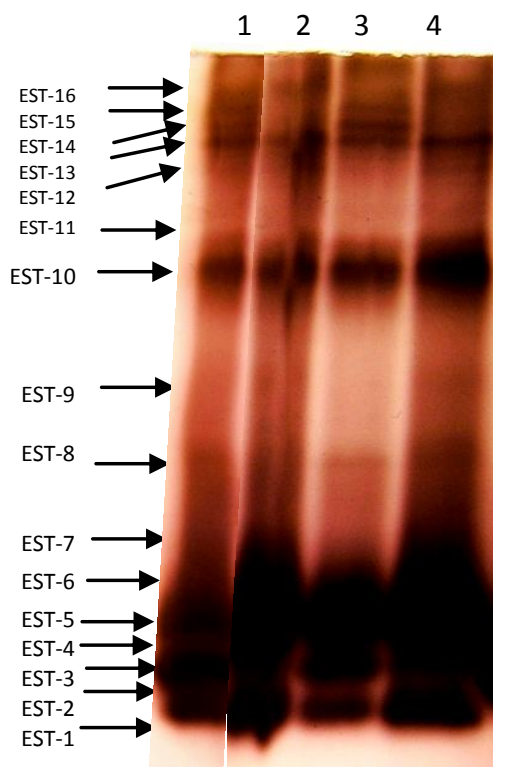

Fig. (4): Native gel electrophoresis of esterase isoenzyme pattern of jojoba shoots grown under the influence of different MS medium strengths containing 3 $\mathrm{mg} / \mathrm{l} \mathrm{BAP}$ and $0.1 \mathrm{mg} / \mathrm{l} \mathrm{NAA}$ for one week. Lane 2 : jojoba shoots on full strength MS medium supplemented, 
lanes 1, 3, and 4 jojoba shoots on half, one and half, and double full MS strength, respectively.

Activated charcoal was often used in plant tissue culture to improve cell growth and differentiation (Thomas 2008; Agrawal et al., 2002). In general, activated charcoal improved jojoba multiplication and in vitro

growth. In six weeks, activated charcoal stimulated shoot multiplication and growth parameters. The positive effect of charcoal application was registered in other works (Abdulwahed, 2013). These values of growth parameters increased when the medium was supplemented with activated charcoal with BAP alone or in combination with low concentration of NAA. The best data was recorded when jojoba explants were cultured on MS medium supplemented with $1 \mathrm{gm} / 1$ activated charcoal in combination with $3 \mathrm{mg} / \mathrm{l}$ BAP and $0.1 \mathrm{mg} / \mathrm{l}$ NAA. Thomas (2008) explained the positive effect of activated charcoal on cultured plant tissues. $\mathrm{He}$ reported that activated charcoal is characterized by fine network of pores with large inner surface area where many substances can be adsorbed. This processes exert positive effects on morphogenesis, it may be due to its ability to absorb of inhibitory compounds in the culture medium and decrease its toxic effect. In addition, activated charcoal has an important role in the release of natural substances which promote growth, increase the darkening of culture media, and adsorb of vitamins, metal ions and plant growth regulators including abscisic acid and ethylene (Thomas 2008).

\begin{tabular}{|c|c|c|c|c|c|c|c|}
\hline $\begin{array}{c}\text { BAP } \\
(\mathrm{mg} / \mathrm{l})\end{array}$ & $\begin{array}{c}\text { NAA } \\
(\mathrm{mg} / \mathrm{l})\end{array}$ & $\begin{array}{c}\text { Activated } \\
\text { Charcoal }\end{array}$ & $\begin{array}{c}\text { Shoot } \\
\text { length } \\
(\mathrm{cm})\end{array}$ & $\begin{array}{c}\text { Leaves } \\
\text { number/ } \\
\text { shoot }\end{array}$ & $\begin{array}{c}\text { Number of } \\
\text { nods / } \\
\text { shoot }\end{array}$ & $\begin{array}{c}\text { Shoot fresh } \\
\text { weight (gm) }\end{array}$ & $\begin{array}{c}\text { Number of } \\
\text { shoots } \\
\text { /explants }\end{array}$ \\
\hline-- & -- & -- & $3^{*}$ & $6^{*}$ & $3^{*}$ & $0.1^{*}$ & $1^{*}$ \\
\hline-- & -- & $1 \mathrm{gm} / \mathrm{l}$ & 5 & 10 & 5 & 0.17 & 2 \\
\hline 4 & -- & $1 \mathrm{gm} / \mathrm{l}$ & 5.5 & 10 & 5 & $0.3^{*}$ & 3 \\
\hline 3 & 0.1 & $1 \mathrm{gm} / \mathrm{l}$ & 5 & $13^{*}$ & $9^{*}$ & 0.3 & $5^{*}$ \\
\hline 3 & 0.1 & - & 5 & $12^{*}$ & $8^{*}$ & 0.2 & $4^{*}$ \\
\hline
\end{tabular}

Table (2): Effect of $1 \mathrm{gm} / \mathrm{l}$ activated charcoal in combination with growth regulators on in vitro multiplication of jojoba shoots growth on MS medium for six weeks.

* Means significantly different (t-test) from jojoba shoots cultured on MS medium supplemented with $1 \mathrm{gm} / \mathrm{l}$ activated charcoal at $\mathrm{P}<0.05$.

When low concentrations of growth regulators (1.25 mg/l BAP and $1.3 \mathrm{mg} / \mathrm{l} \mathrm{NAA})$ were used, the estimated parameters were significantly affected by the concentration of activated charcoal in the medium (Table 3). Shoot length and number of nodes/shoot increased with increase the concentration of activated charcoal. On the other side, the number of leaves decreased significantly with the increase of activated charcoal more than
$0.5 \mathrm{gm} / \mathrm{l}$ medium. It was also registered when the strength of medium was reduced to half strength of MS medium. It was confirmed that the components of medium may be reduced due to the presence of activated charcoal as was reported by several authors. They reported that activated charcoal adsorb hormones (Nissen and Sutter,1990; Ebert et al., 1993), vitamins (Pan and van Staden,1998; Thomas 2008), or metal ions (VanWinkle et al., 2003). Drastic dip in concentration of PGRs and other organic supplements were reported (Thomas, 2008). 


\begin{tabular}{|c|c|c|c|c|}
\hline Ac. Conc. (gm) & $\begin{array}{c}\text { Number of shoots/ } \\
\text { explants }\end{array}$ & Shoot length (cm) & $\begin{array}{c}\text { Number of } \\
\text { leaves/ shoot }\end{array}$ & $\begin{array}{c}\text { Number of } \\
\text { nods/ shoot }\end{array}$ \\
\hline 0.5 & 2 & 4.6 & 14 & 5.3 \\
\hline 1 & 1 & $6^{*}$ & 11.3 & $5.6^{*}$ \\
\hline 2 & 1 & $7^{*}$ & $11^{*}$ & $5.6^{*}$ \\
\hline 3 & 1 & $7^{*}$ & $12.3^{*}$ & $7^{*}$ \\
\hline
\end{tabular}

Table (3): Effect of activated charcoal on shoot multiplication and growth of in vitro grown shoots on half strength MS medium for four weeks.

* Means significantly different (t-test) from jojoba shoots cultured on half strength MS medium supplemented with $1.25 \mathrm{mg} / \mathrm{l} \mathrm{BAP}$ and $1.3 \mathrm{mg} / \mathrm{l} \mathrm{NAA}$ and $0.5 \mathrm{gm} / 1$ activated charcoal at $\mathrm{P}<0.05$.

SDS PAGE of jojoba microshoots under the influence of different concentrations of activated charcoal for one week expressed the same protein patterns (Fig. 5). Variation among the treatments could not be detected. Activated charcoal did not exert significant change in shoot multiplication and protein pattern when the concentration of growth regulators was low $(1.25 \mathrm{mg} / \mathrm{l} \mathrm{BAP}$ and 1.3 $\mathrm{mg} / \mathrm{l}$ NAA) than reqiured for maximum multiplication (3 $\mathrm{mg} / \mathrm{l} \quad \mathrm{BAP}$ and $0.1 \mathrm{mg} / \mathrm{l}$ NAA).

Staining for peroxidase isoenzyme (POX) of jojoba microshoots under the influence of different activated charcoal concentrations for one week is shown in Figure 6. Generally, five isoenzyme forms were detected. No variation in the peroxidase isoenzyme pattern was detected among jojoba microshoots cultured on MS medium supplemented with $(1.25 \mathrm{mg} / \mathrm{l} \mathrm{BAP}$ and $1.3 \mathrm{mg} / \mathrm{l} \mathrm{NAA})$ and different concentrations of activated charcoal $(0.5,1,2$, and $3 \mathrm{gm} / \mathrm{l})$. Both peroxidase and activated charcoal have an important role to prevent the accumulation of brown exudates resulted from phenolic oxidation (Fridborg et al., 1978; Thomas, 2008). Consequently, the applied culture conditions did not stimulate obvious change in peroxidase expression.

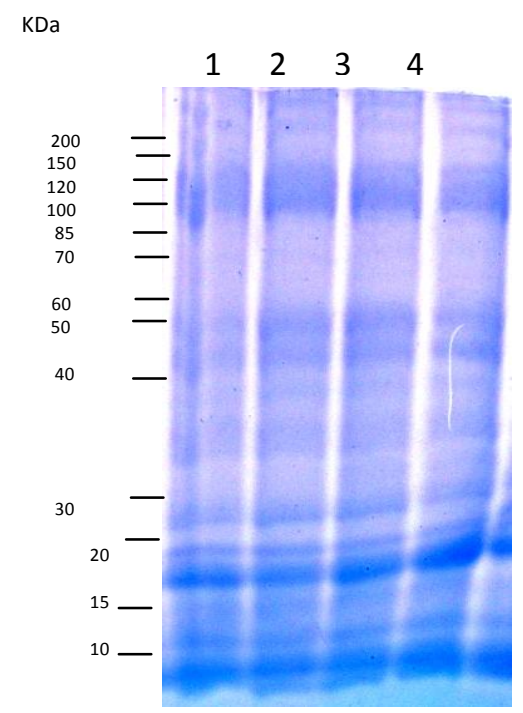

Fig. (5): SDS-PAGE of jojoba shoots cultured for 7 days on MS medium supplemented with $1.25 \mathrm{mg} / \mathrm{l} \mathrm{BAP}$ and $1.3 \mathrm{mg} / \mathrm{l} \mathrm{NAA}$ and $0.5,1,2$, and $3 \mathrm{gm} / \mathrm{l}$ activated charcoal, lanes 1, 2, 3 and 4, respectively.

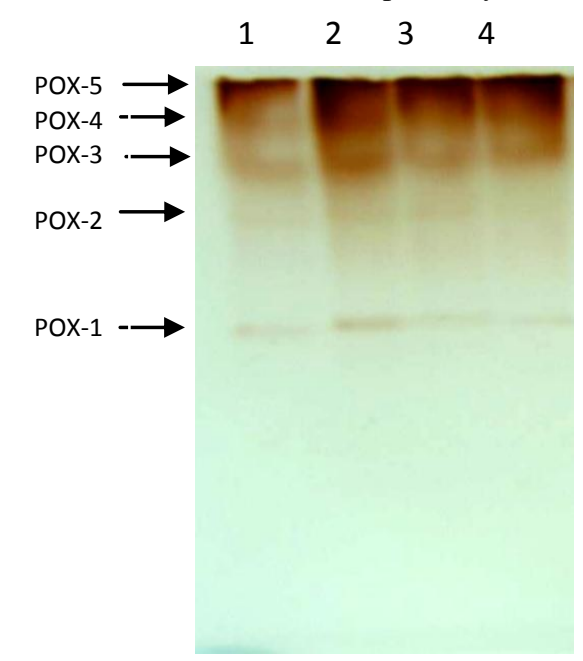

Fig. (6): Native gel electrophoresis of POX isoenzyme pattern of jojoba shoots cultured for 7 days on MS medium supplemented with $1.25 \mathrm{mg} / \mathrm{l} \mathrm{BAP}$ and $1.3 \mathrm{mg} / \mathrm{l} \mathrm{NAA}$ and $0.5,1,2$, and $3 \mathrm{gm} / 1$ activated charcoal, lanes: 1, 2, 3 and 4 , respectively. 
Esterase expression of jojoba microshoots under the influence of different concentrations of activated charcoal was also studied. A total of 16 EST isoenzyme forms were detected (Figure 7). On contrast of SDS-PAGE and peroxidase pattern, the native esterase pattern showed some variation among the used microshoots under the influence of activated charcoal concentrations. It was clear that, culturing of jojoba microshoots on MS medium supplemented with $1.25 \mathrm{mg} / \mathrm{l} \mathrm{BAP}+$ $1.3 \mathrm{mg} / \mathrm{l} \mathrm{NAA}$ and $1 \mathrm{gm} / \mathrm{l}$ activated charcoal (lane 2) resulted in disappearance of 8 isoenzyme forms (EST-1, -6, -7, -8, -9, 10, 11 and -12) in comparison to those of other treatments. Furthermore, staining intensity of bands of jojoba microshoots subcultured on MS medium supplemented with $1.25 \mathrm{mg} / \mathrm{l} \mathrm{BAP} \mathrm{+}$ $1.3 \mathrm{mg} / \mathrm{l} \mathrm{NAA}$ and $2 \mathrm{gm} / \mathrm{l}$ activated charcoal (lane 3) was higher than those of the other treatments. Such changes in isoenzyme expression in jojoba and other plant species suggest that the genes involved in the synthesis of these isoenzymes are differentially activated during development (Chawla, 1991, Hassanein, 2004 a). In addition, the intensity of isoenzyme bands gives indication about the activity of these isoenzymes as was reported previously (Khavkin and Zabrodina 1994; Hassanein, 1998).

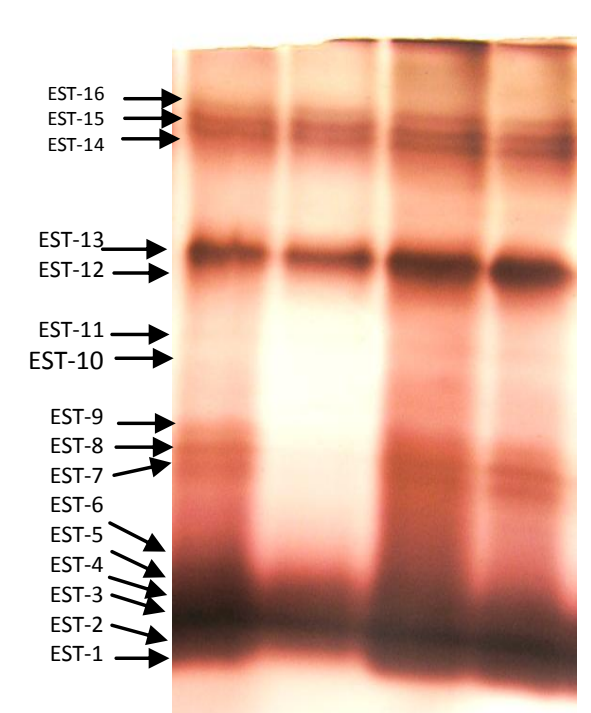

Fig. (7): Native gel electrophoresis of EST isoenzyme pattern of jojoba shoots cultured for 7 days on MS medium supplemented with $1.25 \mathrm{mg} / \mathrm{l} \mathrm{BAP}+1.3 \mathrm{mg} / \mathrm{l} \mathrm{NAA}$ and
$0.5,1,2$, and $3 \mathrm{gm} / 1$ activated charcoal, lane 1, 2, 3 and 4, respectively.

\section{References:}

Abdulwahed, M.S. (2013). Identification of the effect of different levels of activated charcoal and sucrose on multiplication shoots of date palm phenixdactylifera $\mathrm{L}$. C. v. sufedy in vitro. Academic Journals. 5(9): 139-145.

Agrawal, V., Prakash, S. and Gupta, S.C. (2002). Effective prosstocol for in vitro shoot production through nodal explants of Simmondsia chinensis. Biol. Plant. 45: 449-453.

Al-Ani, H.A., Strain, B.R. and Mooney, H.A. (1972). The physiological ecology of diverse populations of the desert shrub Simmondsia chinensis. J Ecolo. 60: 41-57.

Bashir, M., Anjum, M.A. and Rashid, H. (2008). In vitro propagation of some promising genotypes of jojoba (Simmondsia chinensis). African Journal of Biotechnology. 7(21): 3878-3886.

Benson, E.E. and Roubelakis-Angelakis, K. (1994). Oxidative stress in recalcitrant tissue culture of grapevine. Free Radical Biol. \& Med. 10: 355-362.

Benzioni, A., Shiloh, E., Ventura, M. (1999). Yield parameters in young jojoba plants and their relation to actual yield in later years. Industrial Crop Production. 10: 8589.

Brewer, G.J. (1970). Introduction to isoenzymes techniques. Academic Press. New York. San Francisco. London.

Cao, B. and Gao, H.D. (2003). Technology of cutting propagation of Simmondsia chinensis (Link) Schneider (in Chinese). J Nanjing Forest. Univ. 27: 62-66.

Chaturvedi, H.C. and Sharma, M. (1989). In vitro production of cloned plants of jojoba (Simmondsia chinensis (Link) Schneider) through shoot proliferation in long-term culture. Plant Sci. 63:199207.

Chawla, H.S. (1991). Regeneration potentiality and isoenzyme variation during morphogenesis of barely callus. Biologia Plantarum. 33: 175-180. 
Ebert, A., Taylor, F., Blake, J. (1993). Changes of 6-benzylaminopurine and 2,4 dichlorophenoxyacetic acid concentrations in plant tissue culture media in the presence of activated charcoal. Plant Cell Tissue Org. Cult. 33: $157-163$.

Elstner, E.F. and Osswald, W. (1994). Mechanisms of oxygen activation during plant stress. Proc. Roy. Soc. Edinburgh. 102: 131-154.

El-Tayeb, M.A. and Hassanein, A.M. (2000). Germination, seedling growth, some organic solutes and peroxidase expression of different Vicia faba lines as influenced by water stress. Acta Agronmica Hungerica. 48: 11- 20.

Fridborg, G., Pedersén, M., Landstörm, L.E. and Erikson, T. (1978). The Effect of Activated Charcoal on Tissue Cultures.Adsorption of Metabolites Inhibiting Morphogenesis. Physiologia Plantarum. 43: 104-106.

http://dx.doi.org/10.1111/j.1399-

3054.1978.tb01575.x

Hassanein, A.M. (1998). Isoenzyme patterns of Solanum nigrum and the cybrid plant containing $S$. nigrum genome and $S$. tuberosum plastome. Biologia Plantarum. 40: 617- 621.

Hassanein, A.M. (2004a). Hormonal requirement induced different regeneration pathways in Alhagi graecorum. J Plant biotech. 6: 171-179.

Hassanein, A.M. (2004 $)$. Effect of relatively high concentration of mannitol and sodium chloride on regeneration and gene expression of stress tolerant (Alhagi graecorum) and stress sensitive (Lycopersicon esculentum L.) plant species. Bulg. J. Plant Physiol. 30: 19-36.

Hassanein, A.M., Ahmed, A.M., Abdel-Hafez, A.I.I. and Soltan, D.M. (1999a). Isoenzymes expression during root and shoot organogenesis of Solanum nigrum under the influence of different auxins and cytokinins. Biolgia Plant. 42: 341-347.

Hassanein, A.M., Ahmed, A.M., Abed-EI-Hafez, A.I.I. and Soltan, D.M. (1999b). Phenoloxidizing isoenzymes, malate dehyderogenase patterns and organogenesis of Solanum nigrum L. as affected by light treatments. Acta Agronomica Hungarica. 47: 127-136.

Hassanein, A.M., El-Sherbeeny, G.R., Kalid, A.G., Gaboor, G.M. (2015). Seed propagation increases genetic variation and micropropagation to multiply selected shrub with desirable characters. J International Scientific Publications. 3: 325-339.

Hogan, L. (1979). Jojoba: A crop of arid regions. In: New Agricultural Crops. G. Richie.177-205.

Huang, L.C. and Murashige, T. (1977). Plant Tissue Culture Media: Major Constitutents, Their Preparation and Some Applications. Methods in Cell Science. 3: 539-548.

Khavkin, E.E. and Zabrodina, M.V. (1994). Heritable variation in peroxidase and esterase isoenzyme patterns of maize somaclone. Fiziol. Rast. 14: 754-761.

Laemmli, U.K. (1970). Cleavage of structural proteins during the assembly of the head of bacteriophage T4. Nature. 227: 680685.

Lee, C.W. (1988). Application of plant biotechnology for clonal propagation and yield enhancement in jojoba. Proceedings of the 7th International Conference on Jojoba and Its Uses. Phoenix. Arizona. USA. 102 - 111.

Low, C.G. and Hacket, W.P. (1981). Vegetative propagation of jojoba. California Agriculture. 35(3 \& 4): 12 13.

Lu, G., Marshak, S. and Kent, D.V. (1990). Characteristics of magnetic carriers responsible for Late Paleozoic remagnetization in carbonate strata of the mid-continent, U.S.A. Earth and Planetary Science Letters. 99: 351-361.

Mills, D.L., Coffey-Corina, S. and Neville, H.J. (1997). Language comprehension and cerebral specialization from 13 to 20 months. Developmental Neuropsychology. 13: 397-445.

Mohasseb, A.H., Mohamed, K., El-Bahr, M.K., Adam, Z.M., Moursy, H.A. and Solliman, M. (2009). In Vitro Clonal Propagation of Jojoba (Simmondsia 
Chinensis (Link) Schn.). Aus tralian Journal of Basic and Applied Sciences. 3: 3128-3136.

Murashige, T. and Skoog, F. (1962). A revised medium for rapid growth and bioassays with tobacco tissue cultures. Physiol Plant. 15: 473-497.

Nicholson, R.L. and Hammerschmidt, R. (1992). Phenolic compounds and their role in disease resistance. Annu Rev Phytopathol. 30: 369-389.

Nissen, S.J., Sutter, E.G. (1990). Stability of IAA and IBA in nutrient medium to several tissue culture procedures. Hort. Sci. 25: 800-802.

Pan, M.J. and van staden, S.J. (1998). The use of charcoal in in vitro culture. A review. Plant Growth Regul. 26: 155-163.

Radic, S. and Pevalek-Kozlina, B. (2010). Differential esterase activity in leaves and roots of Centaurea ragusina $\mathrm{L}$. as a consequence of salinity. Periodicum Biologorum. 112: 253-258.

Sammons, R.L., Moir, A. and Sm, D.A. (1981). Isolation and properties of spore germination mutants of Bacillus subtilis 168 deficient in the initiation of germination. J General Microbiology. 124: 229-241.

Siegel, B.Z. and Galston, A.W. (1967). The isoperoxidases of Pisum sativum. Plant Physiol. 42(2):221-226.

Thomas, T.D. (2008). The role of activated charcoal in plant tissue culture. Biotechnol. Adv. 26:618-631.

Van Winkle, S., Johnson, S. and Pullman, G. S. (2003). The impact of gelrite and activated carbon on the elemental composition of plant tissue culture media. Plant Cell Rep.21:1175-82.

Wang, Y.C. and Janick, J. (1986). In vitro production of jojoba liquid wax by zygotic and somatic embryos. Journal of American Society of Horticultural Science. 111(5): 798 - 807.

Yermanos, D.M. (1979). Jojoba - a crop whose time has come. California Agriculture. 4 11.

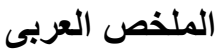

تأثير قوة الوسط الغذائي والفحم المنشط علي التضاعف الخارجي والنمو للأفرع الخضرية لنبات الجوجوبا

$$
\begin{aligned}
& \text { أحمد محمد حسانين، عبد الناصر عبد العال جلال، ضياء الدين محمد سلطان، غاده كامل سعد } \\
& \text { المعمل المركزي للهنسة الور اثية - جامعة سو هاج. }
\end{aligned}
$$

\footnotetext{
ملخص ملتص

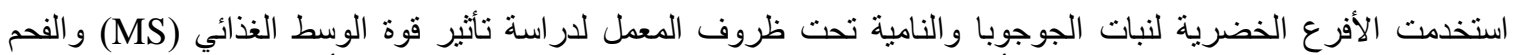

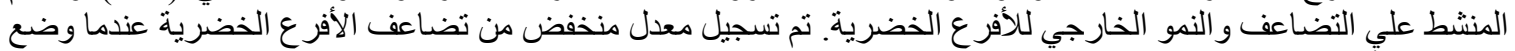

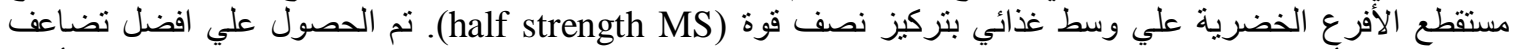

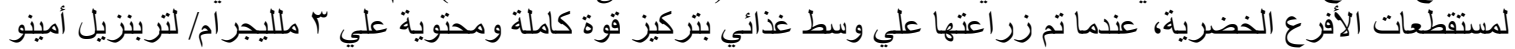

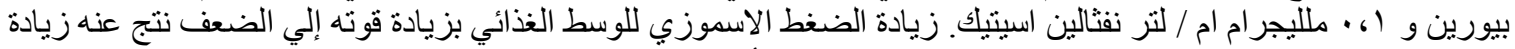

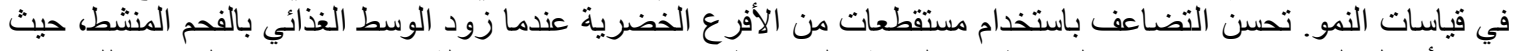

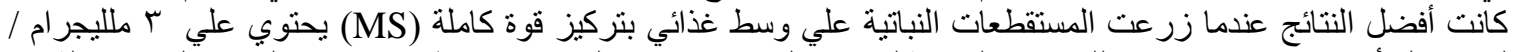

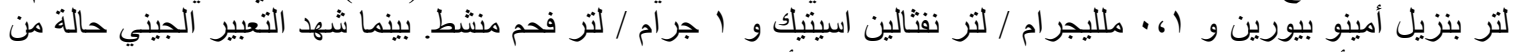

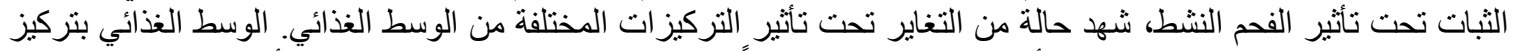

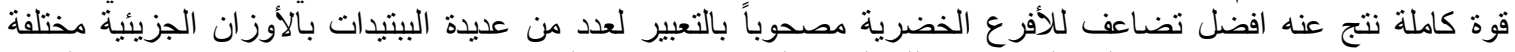

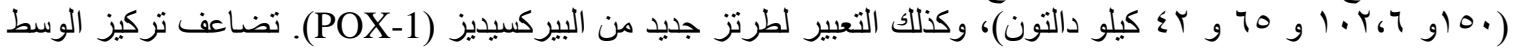

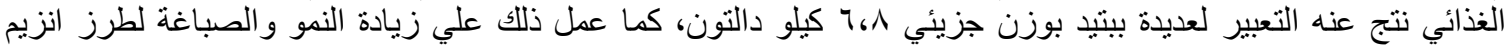

